\title{
Delivering maternal health services in Rwanda: The role of politics
}

Frederick Golooba-Mutebi ${ }^{1}$ with Yvonne Habiyonizeye ${ }^{2}$

October 2018

${ }^{1}$ Independent researcher and Honorary Research Fellow, University of Manchester

Email correspondence: fgmutebi@yahoo.com

${ }^{2}$ Independent researcher

ISBN: 978-1-912593-07-1 


\begin{abstract}
Studies examining the impact of different kinds of organisational and institutional reform on service delivery in the health sector in developing countries highlight and explain advances, strengths, weaknesses, shortcomings and failures in delivery. They rarely explore directly the role of the prevailing political arrangements in individual countries, specifically how politics is organised and practised, in influencing approaches to, and the nature and quality of, service delivery. This paper seeks to contribute towards filling the gap. It explores the extent to which the operation of Rwanda's political system in the light of the prevailing political settlement shapes service delivery and outcomes in the health sector. A political settlement begets specific rules of the game and incentives, constraints, opportunities and risks in its own context. All things being equal, in Rwanda's dominant party/dominant leader political settlement, the short- to medium-term prospects of the current government losing power to opposition rivals are slim. Consequently, there is no pressure on the government to deliver on popular expectations or suffer electoral defeat. In the face of marked achievements in recent times, therefore, the paper explores the possible influences on service delivery in post-genocide Rwanda. It argues that the nature of political organisation and how politics works are decisive.
\end{abstract}

Keywords: Rwanda, RPF, politics, political settlement, service delivery, maternal health, decentralisation, local government

Golooba-Mutebi, F. with Habiyonizeye, Y. (2018) Delivering maternal health services in Rwanda: The role of politics. ESID Working Paper No. 106. Manchester, UK: The University of Manchester. Available at www.effective-states.org

This document is an output from a project funded by UK Aid from the UK government for the benefit of developing countries. However, the views expressed and information contained in it are not necessarily those of, or endorsed by the UK government, which can accept no responsibility for such views or information or for any reliance placed on them. 


\section{Introduction}

Rwanda's health sector has made marked achievements since the Rwandese Patriotic Front (RPF) took over the government in 1994. Some of the more striking gains have been in maternal health. The achievements are the more remarkable when examined against the context of failure or slow change in other developing countries, including Rwanda's neighbours that face more or less similar constraints (Jaffre and de Sardan, 2003; Turshen, 1999). There are several reasons why the health sectors of developing countries perform badly. Preventive health is an area of particular weakness. Household-level studies show that creating awareness through information dissemination about the causes of illness significantly reduces the incidence of ill health (Langwick, 2011; Foley, 2010).

For pregnant women and women of childbearing age generally, this is crucially important. It contributes to a reduction in maternal mortality that stems for the most part from otherwise preventable causes, and to reduction in fertility rates. The causes of maternal and child mortality are well known. Most are preventable or manageable. Direct causes include, among others, obstructed labour and excessive bleeding. Expectant women usually die as a result of delayed access to timely, adequate and appropriate interventions. Delays may stem from factors linked to the supply side of provision, such as health workers absenting themselves from work or starting work late and stopping earlier than officially stipulated (Neema, 1994; Leliveld et al., 2010).

Often, however, delays are related to choices made and actions taken by potential victims, including slow decision-making regarding seeking care, and identifying and going to medical facilities. To a large extent, delay in seeking professional or appropriate interventions is the result of poverty and entrenched beliefs about what is and is not suitable care for specific conditions. The power of misguided beliefs results from lack of information. Awareness creation through information dissemination is therefore a critical aspect of service provision. When neglected, it leads to inadequate overall response to the health needs of the bulk of the population. Other aspects of failure or weakness include poor delivery of important elements of healthcare, such as infrastructure, trained and skilled personnel, and essential medicines and supplies. Accountability is often a key deficit in most developing country contexts (Golooba-Mutebi and Bukenya, 2014; Booth and Cammack, 2013).

This paper examines the provision of maternal health services in rural Rwanda. It describes how delivery happens and the actors involved, directly and indirectly. It shows that there is a strong relationship between the quality of delivery and the degree to which the healthcare system is rule-bound; the degree of vertical and horizontal coordination among the different actors; whether users receive the information they need; whether potential users receive appropriate incentives for seeking the necessary care, and that all this and the uptake of preventive and curative services is heavily influenced by politics. 


\section{Conceptual framework}

The main argument of this paper is that politics is as central to creating conditions that ensure good or poor service delivery as it is to preventing their emergence. To demonstrate this, the paper looks at the evolution of politics in Rwanda since the end of colonial rule. It highlights the origins of drivers of instability and elite fragmentation and the relationship between them and successive political settlements, and their impact on governance and the pursuit of development. Political settlements are the balance or distribution of power between contending social groups and social classes, on which any state is based' (di John and Putzel 2009: 4). The paper concurs that the kind of political settlement arrived at by the most powerful groups in a society (Khan, 2010; North et al., 2009) determines whether peace and stability will prevail and endure, and shapes the commitment and capacity of governments to deliver services and, more broadly, development.

Parks and Cole (2010) contend that stable political settlements or coalitions of powerful groups that bring together key political actors and that are held together by the alignment of interests produce robust political systems that can ensure long-term peace and stability. Conversely, political settlements from which powerful groups that can mount a credible violent challenge or threat to the status quo are excluded remain fragile and do not last. Nonetheless, political settlements are not static, oneoff events, but dynamic 'rolling agreements' among political actors, 'constantly adapting, being contested, and renegotiated', and 'primary in determining the success or failure of state-building and peace-building efforts' (Parks and Cole, 2010: viii). Also, political settlements are located within and closely shaped by the globalised context in which national and transnational actors, institutions, processes and ideas, including international aid, interact (Hickey, 2012).

The paper builds on Levy (2014), who identifies different types of political settlement and defines them according to their character and the degree of their institutional and organisational complexity (ibid: 4). Character refers to how political power is organised, whether according to the dominant-party or dominant-ruler logic or a more competitive logic. According to the typology, the dominant party/ruler variant concentrates power in the party or leader. Meanwhile under competitive clientelism 'political settlements are anchored in a "truce" in which competing forces agree on peaceful rules for political competition' (ibid: 6).

Rwanda's current political settlement is clearly of the dominant type, even though the RPF, which is by far the strongest party, has made a constitutional commitment to formally share power with a handful of very weak alternative parties. Indeed, this expansion of the ruling coalition arguably augments the country's stability and enriches its policymaking (Golooba-Mutebi and Booth, 2013). ${ }^{1}$ It is also important to pay attention to the background, including pre-genocide politics, and contextual

\footnotetext{
${ }^{1}$ Khan labels all such settlements as 'dominant party' (Khan, 2010) but, given the idiosyncracies of the RPF's relationship with the other parties, this description is not quite accurate.
} 
factors that begot the current political settlement. They highlight the motivations behind its emergence and evolution in ways that have shaped relations and institutions that are conducive to delivering high quality services (Booth and GoloobaMutebi, 2012a; Booth and Golooba-Mutebi, 2012b).

\section{The pre-genocide political settlements}

After it became independent in 1962, Rwanda quickly became what Strauss (2006: 182) has referred to as a 'one-party racial dictatorship', in which the Tutsi elite were excluded from politics. The immediate post-colonial political settlement was built around ethnic solidarity within the Hutu majority that felt entitled to political dominance due to its demographic dominance. Before that, Rwandan society had experienced stresses that had accentuated old divisions and begot new ones between the Hutu and Tutsi (Prunier, 1997). The hasty introduction of competitive, adversarial, winner-takes-all, multi-party politics had literally ruled out stability, by spilling inter-elite animosity into the rest of society. The transformation of ethnicity into a political weapon (Strauss, 2006) begot mass violence targeting Tutsi and their moderate Hutu allies. The violence, which had started on the eve of independence in late 1959 , continued to occur until 1973, by which time it had forced large numbers to flee the country (Strauss, 2006). Formerly a Tutsi-dominated monarchy, post-colonial Rwanda quickly evolved into a Hutu ethnocracy.

Whilst his rhetoric indicated a desire to build his power base on the 'Hutu nation', in reality the first post-colonial president, Gregoire Kayibanda, conferred privilege on fellow southern Hutu and pushed northern Hutu to the margins. He banned other political parties, leaving only his MDR-PARMEHUTU. In so doing, he turned Rwanda into a one-party state. He did not last. In 1973, northern-Hutu military officers deposed him and liquidated many of his southern Hutu political allies. His successor, Major-General Juvenal Habyarimana, eventually founded his own party, the National Revolutionary Movement for Development (MRND). ${ }^{2}$ With that, he maintained oneparty rule under dual party and army control (Rusatira, 2005). Habyarimana's idea of inclusiveness consisted of compulsory membership of the ruling party. In the meantime, he accumulated power as holder of numerous formal positions: MRND's founder president, president of its Central Committee, prime minister, army chief of staff, minister of defence, and president of the High Judicial Council (Nkunzumwami, 1996). In 1981, the National Council for Development, ${ }^{3}$ an organ of the MRND, replaced the National Assembly.

Habyarimana presided over a peaceful and stable country for well over a decade. Before 1990, the government neither instigated nor condoned the mass killing of civilians, Tutsi or Hutu (Strauss, 2006), and during that time, Rwanda was a dynamic high-growth economy (Uvin, 1997). Nonetheless, what seemed like a departure from exclusion and marginalisation belied strong undercurrents of continuity, as the new political settlement contained elements of the old one. It was also built around Hutu

\footnotetext{
${ }^{2}$ Mouvement Révolutionnaire National pour le Développement (MRND).

${ }^{3}$ Conseil National de Développement (CND).
} 
pre-eminence within a dominant-party dispensation, under which discrimination became a tool for promoting ethnic and geographical equity. In reality, however, the quotas established to ensure group representation became a mere formality, masking overwhelming Hutu dominance. ${ }^{4}$ Perhaps most significant was the decision not to allow exiles who had fled the violence to return home.

And like Kayibanda before him, Habyarimana promoted regional hegemony, elevating fellow northern Hutu and marginalising southerners. By the mid-1980s, almost the entire leaderships of the army and security agencies were from the North. People from Gisenyi Prefecture, his wife Agathe Kanziga's birthplace, and from his own birthplace, Ruhengeri Prefecture, were over-represented in the leaderships of public enterprises and dominated access to scholarships to study abroad (Reyntjens, 1994). Meanwhile for the Tutsi, possibilities for employment in the army, forces of law and order, and in much of the public sector remained severely restricted. And, as with Kayibanda, Habyarimana's regional bias begot active opposition within the Hutu community. By responding aggressively to this restiveness (Gakusi and Mouzer, 2010), the government left violence as the only option that its opponents could use in their pursuit of power. ${ }^{5}$

Nonetheless, authoritarianism aside ${ }^{6}$ and despite being landlocked and resourcepoor, under Habyarimana Rwanda had a well-managed economy with a strong development track record. ${ }^{7}$ By 1986, for example, agriculture accounted for only 48 percent of GDP, down from 80 percent in 1962. The service sector had grown from 8 percent to 21 percent, and manufacturing from 12 percent to 31 percent. Meanwhile school enrolment had grown to 61.8 percent in 1986, up from 49.5 percent in $1978 .{ }^{8}$ Before the mid-1980s, external debt was considerably lower than the average elsewhere in Africa (28 percent of GNP in 1987). ${ }^{9}$

All this, however, masked brewing crises in the economy and the political arena. By the late 1980s, the economy was ailing because of the collapse of coffee prices. Dependence on foreign aid grew from less than 5 percent in 1973 to 11 percent in 1986 and 22 percent in $1991 .{ }^{10}$ On the political front, at home disenchantment at the MRND's prolonged political monopoly continued to grow, as did alienation by political repression, exclusion and corruption. To prevent or stop agitation for change, the government became more repressive. It led to more turmoil and a drift towards political violence; Callamard, 2000; Adelman, 2000). By coincidence, this was the same period when, having failed to integrate fully in the societies to which they had

\footnotetext{
${ }^{4}$ All 143 mayors, the 10 heads of prefectures and 68 of the 70 parliamentarians were Hutu. Colonel Epimaque Ruhashya was the only senior Tutsi army officer. He had been promoted before Tutsis were barred from senior positions in the army. There was only one Tutsi in the government (Communauté Rwandaise de France, 1990: 25).

5 Interviews with senior RPF cadres, December 2012 and January 2013. Also Otunnu, 2000b.

${ }^{6}$ Reyntjens (1994); Prunier (1997); also Uvin (1997).

${ }^{7}$ See, for example, Reyntjens (1994:35); also Prunier (1997).

8 Prunier, ibid.:101.

${ }^{9}$ Reyntjens, op.cit.:35.

${ }^{10}$ Prunier, op.cit.:102.
} 
fled in search of refuge, exiles were intensifying their efforts to ensure that they returned home ${ }^{11}$ efforts that had long been opposed by both the Kayibanda and Habyarima governments.

In the midst of the continuing stalemate, the exiles opted to force their way back into the country, at which point they founded the Rwanda Patriotic Front (RPF). Through the RPF they would challenge the prevailing political settlement in Rwanda and overturn it if necessary (Otunnu, 2000a; Prunier, 1997). On 1 October 1990, RPF's armed wing, the Rwanda Patriotic Army, took up arms and invaded the country from Uganda. The attack accentuated fear and suspicion between the Hutu and Tutsi communities inside the country, and prepared the ground for elite demagogues to incite anti-Tutsi violence. The violence culminated in the genocide against the Tutsi and, eventually, the RPF's seizure of power. ${ }^{12}$ And so both the Kayibanda and Habyarimana governments support the contention by Parks and Cole (2010), that political settlements that exclude powerful potential adversaries who can mount an armed challenge stand little chance of enduring.

\section{The post-1994 political settlement}

At the end of the war, it was widely believed that the Rwanda the RPF had inherited was destined to be a failed state. The state had collapsed and, with it, the economy. However, within a short time, the state had 're-affirmed itself vigorously'. ${ }^{13}$ Over the last 24 years, significant progress has been made in a wide range of domains, among them, the health sector. What has enabled the government to achieve this success? This section examines the role of politics within the context of an RPF-led reconfiguration and re-ordering of the political system.

\section{The new politics of consensus}

Upon seizing power, the RPF embarked on turning politics in Rwanda decisively away from its previously winner-takes-all orientation. In conformity with the externally brokered Arusha Accords, to which all the rival political forces had agreed, the RPF began by forming a multi-party government, bringing together different political groups. Only two parties, MRND and CDR, seen as bearing the greatest responsibility for planning and executing the genocide, were excluded through an outright ban. ${ }^{14}$

The 1993 Arusha Agreement envisaged a conventional multi-party system bearing the usual fiercely competitive and adversarial elements, complete with a conventional

\footnotetext{
11 See, for example, Muganwa (2012), also Gachuruzi (2000); Otunnu (2000b). Also interviews with former members of the Rwandan Diaspora in former Zaïre, Burundi, and Uganda (2005-06).

${ }^{12}$ For details of how the war and the internal crisis unfolded, both of which are beyond the scope of this paper, see, for example, Gourevitch (2000); de Forges (1999), Prunier (1997).

13 Reyntjens (2004.:209).

${ }^{14}$ However, individual former members of the MRND who had not participated in planning or executing the genocide, or who were accused of involvement and then absolved by the Gacaca courts, were not excluded. Many took up important roles in the post-genocide government, some as members of the RPF.
} 
opposition. If adopted, it would exclude groups that did not possess the capacity to win elections. However, driven by the history of political exclusion and its consequences, of which its membership had been victims for over three decades, the RPF, despite its overwhelming dominance as the only armed political organisation, brought their potential rivals and adversaries into the government, instead of excluding them. ${ }^{15}$

Political parties would continue to exist, albeit under a legal framework restricting their activities and preventing them from operating outside the capital city, Kigali, during a transitional period. The aim was to prevent disruptive adversarial contestation at a time when the country was still dealing with the fall-out from the precipitate return to multi-party politics in the late 1980s. These measures allowed the RPF the necessary space to lay the foundations of 'a new Rwanda' and to consolidate its authority. For the smaller parties, the government of national unity presented opportunities for playing key roles and acquiring experience in statecraft. Also significant was the rejection of the approaches that the Kayibanda and Haybarimana governments had adopted for promoting inclusion. Regionalism and ethnicity were no longer to serve as grounds for citizens making claims on the state. Citizenship would henceforth underpin the principle of equality of access to opportunity. The new approach was concretised through the abolition of the national identity card that bore ethnic labels.

It is worth pointing out that all this happened amidst challenges. Some of them became the basis of widespread criticism of the RPF-led government and its leadership by media, academia and human rights activists. Much of the critique has focused on violation of human rights, including freedom of association and speech; suppression of media freedoms; exclusionist practices, and opposition to democratisation (Reyntjens, 2013). A full examination and evaluation of the critique is beyond the scope of this paper. However, it largely disregards the ruling coalition's inclusive elements and the protracted negotiations that preceded its birth.

Claims of continued discrimination ought to be weighed against the government's cross-ethnic and cross-regional composition and the ever-shifting make-up of influential people within both the government and the RPF itself as a result of reshuffles, sackings and re-deployment. ${ }^{16}$ True, changes in the government's composition represent episodes of falling out of favour for some officials from time to time. However, they also point to a fundamental change in the way things work in Rwanda. Unlike under Habyarimana, when members of the so-called akazu (inner circle) were untouchable, under the current government there are no sacred cows that can get away with wrongdoing because of their political or social status or connections.

\footnotetext{
${ }^{15}$ Long before the RPF captured power, it had established contact with several anti-MRND parties with similar aspirations to its own (interviews with the non-RPF party leaders since 2012).

${ }^{16}$ These shifts are usually portrayed by critics as evidence of 'divisions within the RPF', which, some assert, point to its imminent collapse.
} 
The critique focusing on limits on free political expression, independent civil society and media freedom is hardly misplaced. However, it can be misleading in its broadbrush orientation. Close scrutiny of the limits imposed on some freedoms, such as freedom of speech, suggests that they can be best understood when properly contextualised. First, one has to bear in mind the roles they played in fomenting the genocide against the Tutsi. Second, one has to take into consideration the weeks of negotiations that begot the current political settlement and its emphasis on consensus-building and rejection of adversarial contestation (Golooba-Mutebi and Booth, 2013). An important principle, as explained by a senior official, is: 'if you fight us, we fight you back'. The official view regarding how civil society organisations and the government should relate to each other clearly underlines the government's aversion to contestation and preference for consensus building:

There are two debates on the role of civil society organisations in developing countries by international scholars. On one side, civil society is seen as a counter power to government and, on the other, civil society is seen as an effective partner in the service delivery and development process. Rwanda favours the latter approach. ${ }^{17}$

This is important, for many reasons. For example it is unlikely that the acclaimed rapid recovery the country has achieved over the last two decades (Kinzer, 2008; Crisafulli and Redmond, 2012) would have been as easily achievable in the absence of a broad internal elite consensus around the rules and values that have guided post-war reconstruction and state-building. Unlike in other post-war dispensations practising conventional multi-party competition, including its neighbours, in Rwanda political groups that are party to the current political settlement take the view that differences are best resolved through dialogue, not through avenues that are potentially disruptive of public order. ${ }^{18}$ For the government, the benefit of this approach lies in the way it strengthens prospects for long-term stability by, among other things, allowing meagre resources and collective efforts to be directed at doing those things, such as service delivery, that serve the interests of the ordinary citizen and the country as a whole. Most importantly, it allows for long-horizon planning and public goods delivery and renders short-term political calculus, focused on narrow considerations of regime maintenance, unnecessary. Achievements in health illustrate its benefits in one sector.

\section{Approach and methods}

Overall, the research that informs this paper dates from 2006 and is based on primary and secondary sources and hundreds of interviews with a wide range of actors. However, we conducted the specific research on maternal health in Kigali and in two rural districts over a period of five months in 2015. During the first two months, we interviewed high-level health professionals and political leaders at the Ministry of

\footnotetext{
${ }_{17}^{17}$ Maina and Kibalama (2006: 66).

18 Interviews with politicians across a range of political parties in and outside government, December 2012 to February 2013
} 
Health and those that have previously served there, including former ministers. We then interviewed government officials operating outside the health sector, but whose functions entail occasional or regular interactions with officials at the Ministry of Health on matters pertaining to the management and functioning of the sector.

Other respondents included senior officials of the ruling party whose functions bring them into regular or occasional contact with health ministry officials, and others responsible for thinking about, influencing or coordinating the party's, and ultimately the government's, thinking on matters related to the social sectors. Senior officials of other political parties who have served or continue to serve in the government, but also those who are not in government but have insights into how the political system works and has evolved, were also interviewed.

Other interviews took place within the two districts, Ngororero in the Northwest, and Kamonyi in the South close to Kigali, with the following people: district mayors and their deputies in charge of the social sectors, lower-level local government officials, both elected leaders and technicians, health insurance managers, health personnel at district hospitals and lower-level health units, community health workers, data managers, health insurance officials, social workers and some service users. Interviews were supplemented with observation at the different health units where they took place. Altogether over 150 interviews were conducted.

Selecting the study districts was not so straightforward. Performance by districts in many domains is remarkably high. Consequently, a district may come in at the tail end of a performance league table, having achieved up to 80 percent of a specific undertaking, while those at the higher end have achieved more than 90 percent. As a result, save for exceptional cases, no district can be considered a poor performer, strictly speaking. Such is the spirit of competition and the drive to achieve engendered by regular assessments and evaluations, that performance across the country is, on the whole, high (Figure 1). In selecting the two districts, therefore, we considered their performance with regard to maternal health indicators (Figures 2 and 3).

We wanted to compare a district that tended towards the higher side of the scale with one that tended to the lower side. At the time of the research, Ngororero district had the 12th highest rate of health-unit deliveries (90 percent), while Kamonyi came in at number 18 (82 percent). Also, in 2014, five expectant women had died in labour in Ngororero, while in Kamonyi only two had died. However, performance was not the only criterion for selecting the case studies. Other important considerations were accessibility and whether the research team could find suitable accommodation. Distance from the capital city, Kigali, was also important. We wanted a district within relatively easy proximity, which might derive advantages from that, and also one that was at considerable distance and therefore shielded from urban influences. 
Figure 1: Immunisation coverage by district

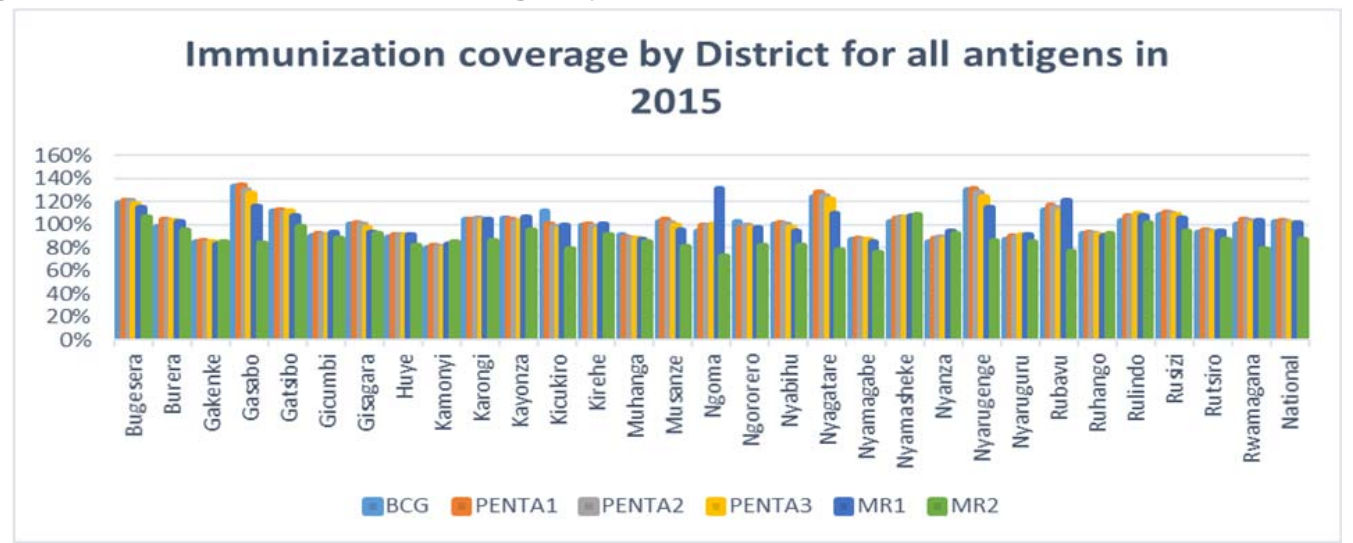

Source: $\mathrm{MoH}$.

Figure 2: One (first) antenatal care visit by district

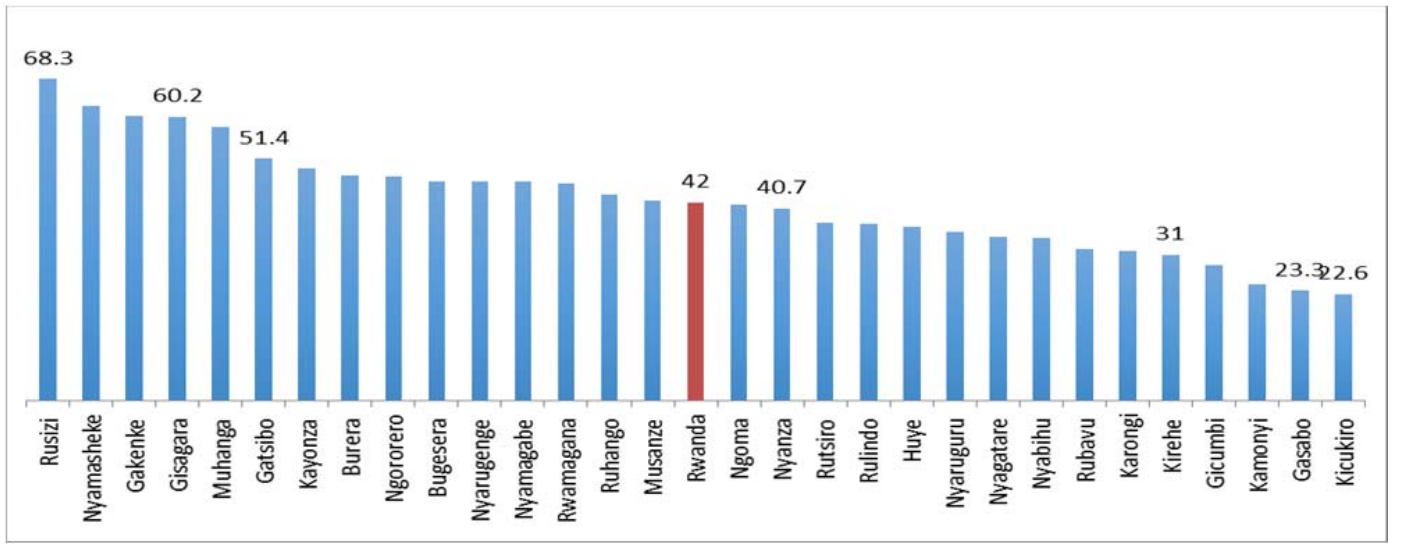

Source: Health Management Information Systems (HMIS) 2015.

Figure 3: Four antenatal care visits by district

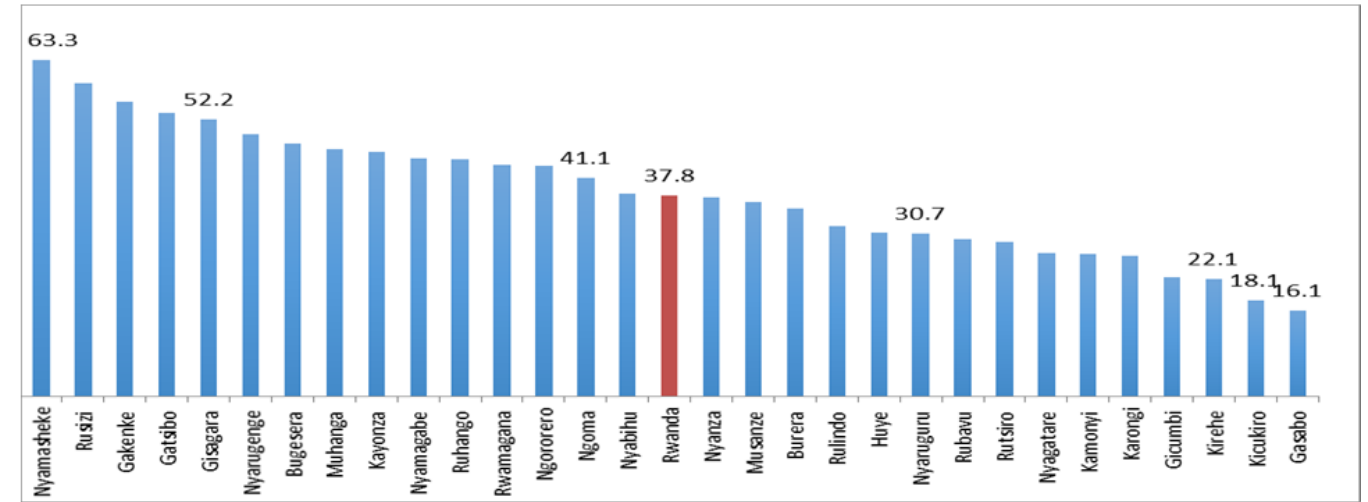

Source: HMIS 2015.

Ngororero is over two hours' drive from Kigali, while Kamonyi is about 45 minutes to an hour away.

\section{Trends in maternal health}

Rwanda has made remarkable gains in maternal health over the last two decades. Far more expectant women seek antenatal care (ANC) than used to be the case just 
over a decade ago. Equally large numbers deliver under the care of professional health workers. Also, more women now use family planning. This has led to a significant drop in overall fertility rates and reduced the risk of uncontrolled births for women's health and wellbeing (Table 1). This is why the maternal mortality rate has dropped drastically in only 15 years (Figure 4). How has Rwanda done it?

Table 1: Fertility and maternal health indicators ${ }^{19}$

\begin{tabular}{|l|c|c|c|c|c|c|}
\hline $\begin{array}{l}\text { Yearl } \\
\text { Indicator }\end{array}$ & $\begin{array}{l}\text { Fertility } \\
\text { rate }\end{array}$ & $\begin{array}{l}\text { Contraception } \\
\text { use (\%) }\end{array}$ & $\begin{array}{l}\text { 1ANC } \\
(\%)\end{array}$ & $\begin{array}{l}\text { ANC 4 } \\
\text { times } \\
(\%)\end{array}$ & $\begin{array}{l}\text { Assisted } \\
\text { delivery } \\
(\%)\end{array}$ & $\begin{array}{l}\text { Delivery } \\
\text { at health } \\
\text { units } \\
(\%)\end{array}$ \\
\hline 2000 & - & - & - & - & - & - \\
\hline 2005 & 6.1 & 17 & 94 & 13 & 39 & 30 \\
\hline 2008 & 5.5 & 36 & 96 & 24 & 52 & 45 \\
\hline 2010 & 4.6 & 52 & 98 & 35 & 69 & 69 \\
\hline 2015 & 4.2 & 53 & 99 & 44 & 91 & 91 \\
\hline
\end{tabular}

Source: Demographic and Health Surveys (DHS) 2015.

Figure 4: Trends of maternal mortality ratio over the last 15 years

Maternal Mortality Ratio form the RDHSs 2000, 2005, 2010, and 2014-15

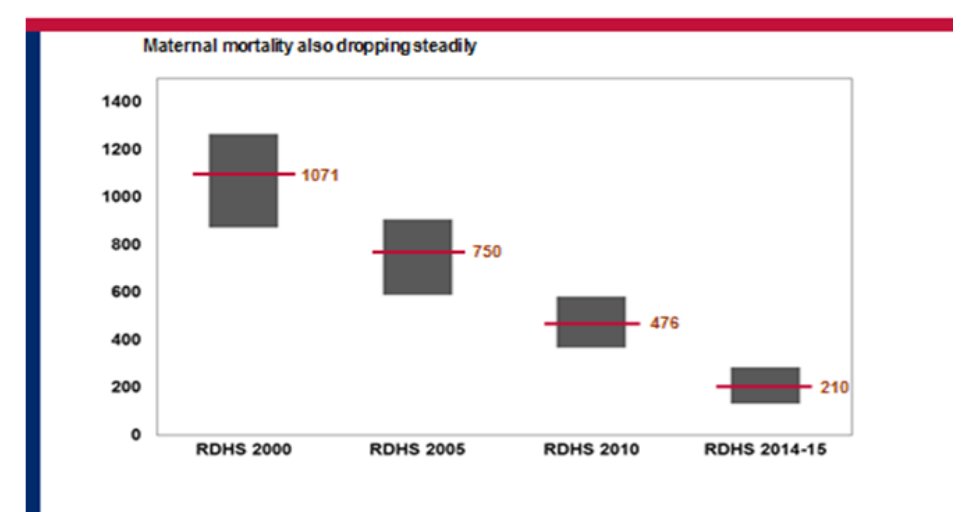

Source: DHS 2015.

\section{Factors underlying Rwanda's gains}

\section{The role of the central government}

There are three approaches to service delivery in rural Rwanda: purely public (government); public-private partnerships, entailing the pooling of efforts between the

\footnotetext{
${ }^{19}$ There are some discrepancies between DHS and HMIS data, the explanation being that RDHS data are collected from a survey over a five-year period, while HMIS data are administrative data that are collected on a monthly or quarterly basis and keep changing regularly. For judging impact over a longer period therefore, DHS data are more reliable (personal communication, planning directorate, Ministry of Finance and Economic Planning, 28 June 2018).
} 
government and faith-based providers; and private practice (Table 2). The government is by far the largest provider, channelling its services through a network of health centres and health posts located at lower levels of the local government system (cell and sector), and hospitals at district level.

The largest private providers are faith-based organisations, mainly the churches. They have their own health facilities. However, they are staffed, supplied, equipped and overseen in their operations by the Ministry of Health. The ministry's role is to ensure that these private entities are subject to the same exacting performance requirements as public ones. This is why, unlike in other countries with more or less similar socio-economic characteristics as Rwanda, such as Uganda, for example, private and public facilities provide the same quality of services, exhibiting more or less similar strengths and weaknesses. Although they remain the property of the faith-based organisations, which continue to have a say in how they are run, these facilities are fully integrated into the public healthcare system, enjoying less autonomy than their counterparts in Uganda, for example (Golooba-Mutebi and Bukenya, 2014).

There are also individual, registered private practitioners owning and operating licensed clinics, pharmacies and drug shops. ${ }^{20}$ There are several private drug shops in rural towns and trading centres. Private pharmacies and clinics, however, are rare. ${ }^{21}$ One explanation for the absence of private pharmacies and clinics in rural areas is that there is hardly a market for their services because of the reasonably high quality and predictability of services offered by government and governmentassisted facilities. Also, members of the public who might otherwise use the services of private pharmacies and clinics are for the most part locked into services offered by the public sector and its allied government-assisted private sector by the mandatory community health insurance subscriptions. ${ }^{22}$

In many African countries, traditional birth attendants (TBAs) account for most deliveries outside the formal healthcare system (Booth and Cammack, 2013). However, in Rwanda their activities have long been outlawed. They face predictable sanctions if caught attending to expectant women. However, rather than leave them without occupation, many former TBAs have been recruited as community health workers. They provide advice to expectant women and ensure that they go for antenatal check-ups and that they deliver at health facilities. They are attached to

\footnotetext{
${ }^{20}$ Drug shops are small stores in rural areas that belong to people with requisite healthrelated qualifications and are allowed to stock and sell medicines, but under greater restrictions as to what they can and cannot sell than pharmacies, which must belong to or be managed by qualified pharmacists.

${ }^{21}$ The research team did not come across unregistered private practitioners running unlicensed operations, or facilities run by charities or NGOs.

${ }^{22}$ Rwanda has a highly subscribed community health insurance scheme (mutuelle de santé) under which citizens who are not employed in the formal public or private sector pay relatively small amounts of money in premiums per year in return for low-cost, high-quality medical care.
} 
specific health facilities and work under the direct supervision of formally trained health personnel.

The strict control over, and regulation of, the health sector rules out the emergence of unregulated and unlicensed health services that in other developing countries constitute alternative sources of care, where government services are dysfunctional and formal private provision is unaffordable for many. Where they exist, as in Uganda, for example, unlicensed providers can be death traps for users, including expectant women, who are often taken there because their families cannot afford transport fees to distant government facilities, let alone money to pay at the more expensive registered private facilities.

Table 2: Number and types of health facilities (2013-15)

\begin{tabular}{|l|r|r|r|r|c|}
\hline \multicolumn{1}{|c|}{ Heath facility type } & 2013 & 2014 & 2015 & $\begin{array}{c}2015 \\
\% \text { of total }\end{array}$ & $\begin{array}{c}\text { \%change } \\
(2014-15)\end{array}$ \\
\hline National referral hospitals & 5 & 8 & 8 & $0.7 \%$ & $0.0 \%$ \\
\hline Provincial hospitals & 0 & 4 & 4 & $0.3 \%$ & $0.0 \%$ \\
\hline District hospitals & 42 & 35 & 35 & $2.9 \%$ & $0.0 \%$ \\
\hline Police hospital & 1 & 1 & 1 & $0.1 \%$ & $0.0 \%$ \\
\hline Health centres & 465 & 478 & 495 & $40.5 \%$ & $3.6 \%$ \\
\hline Prison dispensaries & 15 & 15 & 15 & $1.2 \%$ & $0.0 \%$ \\
\hline Health post & 32 & 380 & 406 & $33.3 \%$ & $6.8 \%$ \\
\hline Private dispensaries & 137 & 113 & 123 & $10.1 \%$ & $8.8 \%$ \\
\hline Private clinics & 84 & 91 & 95 & $7.8 \%$ & $4.4 \%$ \\
\hline $\begin{array}{l}\text { Community-owned health } \\
\text { facility }\end{array}$ & 15 & 15 & 13 & $1.1 \%$ & $-13.3 \%$ \\
\hline $\begin{array}{l}\text { Voluntary counselling and } \\
\text { testing centre }\end{array}$ & 20 & 21 & 26 & $2.1 \%$ & $23.8 \%$ \\
\hline Total & $\mathbf{8 1 6}$ & $\mathbf{1 1 6 1}$ & $\mathbf{1 2 2 1}$ & $\mathbf{1 0 0 . 0 \%}$ & $\mathbf{5 . 2 \%}$ \\
\hline
\end{tabular}

Source: HMIS database, 2015.

Strict regulation also means that, because it is difficult to opt out of public provision, users are more likely to complain when dissatisfied with the quality of services offered by the only sources of provision available: government and governmentassisted facilities. Indeed, one of the remarks health workers made about service users was that they complain too much. That they complain is evident in the fact that service users write their complaints and insert them in the suggestion boxes that are placed at the entrances of health facilities. In some other countries they remain unused for the most part (Golooba-Mutebi and Tollman, 2007). In Rwanda, because they are used, deputy mayors in charge of social affairs empty them regularly and review the contents. The information is then used to inform decision-making during routine district-level social-sector meetings. ${ }^{23}$

\footnotetext{
${ }^{23}$ Each district has two deputy mayors, one in charge of economic development and finance, the other in charge of social affairs. The deputy mayors keep the keys to the boxes and only
} 


\section{Day-to-day management of service provision}

\section{The set-up}

In Rwanda, the district is the basic service delivery unit. It is the vehicle through which the government tries to respond to the complex needs of local populations and to achieve its goal of universal health coverage. The health system is organised in line with the country's decentralised local government framework. Overseeing the sector is the District Secretary for Social Affairs in charge of health. Each district has at least one district hospital headed by a medical officer, and a network of lower-level government and government-assisted facilities. There is also a government-owned district pharmacy that supplies drugs and sundries to all government or governmentassisted facilities. In addition, there are licensed private drug shops and pharmacies. In the bigger towns, one may find private clinics. The district administration organises and oversees the delivery of minimum and complementary services through management of logistics and resources and supervision of personnel, including community health workers.

Under the decentralisation framework, ${ }^{24}$ the government has embraced the principle of popular participation in service provision. Local communities play roles in decisionmaking in order to ensure that decisions arrived at correspond to their needs and priorities. Underlying this approach are three assumptions about what popular participation can achieve:

- Ensure transparency in decision-making, thereby rendering local leaders accountable to their communities.

- Ensure that local leaders respond to the needs of local communities.

- Ensure that supervision and monitoring are effective, because participation narrows gaps between service users and local officials who are responsible for service delivery.

\section{Service delivery in practice: The importance of inter-level linkages and collaboration}

\section{Oversight}

Nurses, midwives and auxiliary personnel run and manage all the health facilities below hospital level. At the district level, political leaders and professional medical personnel oversee service provision on behalf of the Ministry of Health. Directors of district hospitals and their (hospital-based) staff supervise lower-level health facilities

they or their representatives can open them (interviews with health workers and local leaders, July 2015).

${ }^{24}$ Rwanda's decentralisation programme has been implemented in phases. Phase 1 (200005) established the primary community structures and strengthened the core unit of local government, the district. Phase II (2006-10) placed emphasis on enhancing effectiveness by making the sector (Umurenge) the focal point of service delivery. Phase III, which is underway, envisages decentralising some responsibilities to lower-level administrative units, with the cell (umudugudu) as the service delivery point. 
below the district. Supervision is through physical inspection and mentoring of their less qualified and less experienced colleagues. On the whole, health facility inspection, which takes place alongside interaction among higher-level personnel and their lower-level colleagues, are regular and frequent. In addition, the Ministry of Health periodically sends teams of inspectors to hospitals to conduct thorough audits focusing on a wide range of domains, including general hygiene, staff punctuality, prescription and management of medicines, and the use and management of assets such as equipment - including furniture, power generators, vaccine refrigerators, and beds in wards - and vehicles. All this leaves little room for the absenteeism and misconduct, both of which bedevil health services in countries such as Uganda, Malawi, Niger, and others across Africa (Booth and Cammack, 2013).

\section{Accountability and the role of mentoring}

There are strict reporting requirements. Lower-level facilities must, on a regular basis, at pre-determined intervals, submit a range of reports to district hospitals, district administrations, and to the Ministry of Health, simultaneously or separately. Hospitals, too, submit reports to the district administration and to the ministry on a regular basis. The reports must be delivered on time, which sometimes compels facility-level data managers and clerks to work extra hours, sometimes through the night, in order not to miss deadlines. Inter-level reporting is reinforced by the requirement that the officials for whom the reports are prepared follow up on matters that call for closer attention. Follow-up could be in the form of phone calls, written requests for more information, or on-site visits by the concerned higher-level officials, including ministers.

The reports usually focus on actual situations or events. Doctors and other personnel from referral hospitals visit health centres under their jurisdiction to inspect them and also to provide advice and training in diagnosis, prescription and treatment. The objective is to minimise avoidable mistakes that may harm patients. Personnel at lower-level health units in turn supervise and oversee the work of the community health workers in each village within their units' catchment areas.

Another accountability mechanism is the requirement that all health workers place their photographs accompanied with their names, official designations, phone numbers, and email addresses on public display. They are required to pin them up on the doors of their offices or on the walls or noticeboards of health facilities. For example, all personnel working in a specialised HIVIAIDS section must have their details on display at its entrance. This enables patients or members of their families who find the office locked to contact the concerned health workers by telephone.

In case the missing staff cannot be reached, the matter could be taken up with the head of the facility, whose details can also be found on their office door should they not be on the premises. Some mayors go as far as providing their phone numbers to members of the public and encouraging them to call and report on the quality of service and other concerns. The mayor of Kamonyi District at the time of the 
research reported that people used to call him to raise their concerns or complain about aspects of service provision. Health workers confirmed that he in turn would call the facility heads to establish what had happened and urge them to take the necessary corrective measures.

Supplementing all this are suggestion boxes prominently displayed at health facilities and notices on notice boards spelling out patients' rights or providing phone numbers that service users can call and report their concerns or complaints. It is not clear how many service users actually take advantage of these accountability mechanisms. Also, it is possible that some of them, such as calling the various telephone numbers on public display, are beyond the reach of ordinary citizens because of associated costs. However, that they exist and that efforts are made to publicise their existence to the public testifies to the Rwandan authorities' drive to ensure that service providers are held to account. Also, it means that health workers make every effort to avoid becoming the target of complaints that could jeopardise their careers.

\section{Attracting users by taking care to the community}

Some community health workers (also known as binomes) are specifically responsible for following up and advising pregnant women. They monitor and keep in touch with them, encouraging them to go for antenatal check-ups and providing whatever other advice is necessary. Where necessary, which is more often than not, they accompany those in labour to the health units to deliver there, under professional observation.

Increasingly fewer women deliver at home or outside health facilities. The small number who do, do so mostly by accident. It usually happens while they are on their way to a health facility or when they are unable to walk to a facility and evacuation takes too long to organise. In the past, women who chose deliberately to deliver from home risked being fined. The fining might take place when they went to register their babies' births with the local authorities, and when they took them for immunisation at health facilities.

Expectant women who seek to avoid being caught up in complicated emergency situations or in sudden onset of labour pains and the associated risk of delivering outside health units, can do so. They can take advantage of rooms (tegereza) that have been set aside at some health units that have rooms to spare, where they can stay free of charge for up to two weeks while awaiting delivery. Women attending their last antenatal check-ups are informed of their approximate due dates and advised to report for delivery a few days before. In both Ngororero and Kamonyi districts, service users did not complain about nurses and midwives being rude to, or insensitive towards, expectant women, as they do elsewhere (Booth and Cammack, 2013; Jewkes et al., 1998). The sensitivity and consideration with which they are attended to must serve as an added incentive for seeking to deliver at health facilities. Community health workers use short messaging service (SMS) to alert health workers of cases requiring emergency response within communities. Where 
evacuation of patients is necessary, SMS messages trigger its coordination by facility personnel. ${ }^{25}$ Evacuations cannot be organised promptly in all cases, thus the reason some women still deliver outside health facilities. However, where evacuation fails, it is usually the result of complex logistical reasons, such as difficult physical terrain.

\section{Ministry of Health: The significance of top-down accountability mechanisms}

The diligence with which health facilities are supervised is the product of accountability mechanisms through which the Ministry of Health in Kigali supervises district hospitals and ensures that they, in turn supervise lower-level health facilities. Also, there are health unit management committees (comités de gestion) at the facility level. They hold monthly meetings through which they ensure that health units function and deliver services as stipulated in regulations and guidelines and as expected by users - who have become accustomed to being attended to without much delay and with sensitivity and consideration, and who usually complain when their expectations are not met.

As a result of consistent oversight, health units open their doors to users promptly at the designated times and are clean and under normal circumstances well stocked with drugs and sundries. Drugs are supplied almost exclusively by the usually wellstocked government-owned district pharmacies, which are in turn supplied by the central medical stores (CAMERWA). Thanks to the advances Rwanda has made in the field of information and communications technology, ${ }^{26}$ district pharmacies track online the availability of medicines and other supplies at all health units, just as CAMERWA tracks availability at district pharmacies. This tracking, and the careful scrutiny of prescriptions by facility-based health insurance personnel before they authorise payment, for the most part rule out mismanagement, diversion or theft of medicines that is so common in other countries. Health units are authorised by the district pharmacy to purchase drugs on the open market only if no other district pharmacy within easy reach has the required drugs in stock.

\section{User-provider interactions}

Tracing the roots of successful delivery of maternal health services in Rwanda ought to start where contact between a pregnant woman and the formal health sector begins. It begins with the woman attending her very first antenatal check-up. The visit may be at the woman's own initiative, or on the urging of a community health worker. Community health workers play an important role in raising awareness among women of childbearing age about the importance of antenatal check-ups during pregnancy.

\footnotetext{
${ }^{25}$ Some villages are able to organise evacuation using hammock-like traditional ambulances (ingobyi), while in other cases patients' families do so with the assistance of community health workers.

${ }^{26}$ Gagliardone and Golooba-Mutebi (2016).
} 
Upon first contact, both the expectant woman and the health workers have obligations to fulfill. Women are encouraged to take their husbands or partners along. This enables health-unit-based social workers to counsel both partners about the importance of HIVIAIDS testing and health workers to conduct the necessary tests. Couples that are found to be HIV positive receive advice about how to conduct themselves henceforth, both for their own wellbeing and that of the unborn child.

Much emphasis is laid on the prevention of mother-to-child transmission. In the past, where male partners refused to turn up, there were measures to compel them to do so, including sanctions. Local leaders would be notified. They in turn might dispatch community policing agents to accompany them to the health facilities where they were required to report (Chambers and Golooba-Mutebi, 2012). Although seemingly draconian, these measures were intended to minimise the spread of HIVIAIDS by people who did not know their status and who did not possess information about how to manage their condition.

If for some reason the partner could not be found and the woman was still resident at her parents' home, she would have to be accompanied by her father. This was meant to enable the father, under whose authority she lived, to become aware of the situation and of the measures required to deal with it. Today public education campaigns have rendered compulsion rare. Public awareness campaigns have ensured that men are better informed about the importance of testing for HIVIAIDS. Nonetheless, there are still cases where men refuse to turn up voluntarily. In such instances, the women are counselled and tested and then the results are withheld until the man agrees to be counselled and tested. It is not clear what happens if the man does not change his mind.

There are also women who may not heed the advice of community health workers to go for antenatal consultations. They come under subtle pressure through visits by local leaders or health workers for further sensitisation. The involvement of local leaders is both out of concern for the wellbeing of members of their communities, and out of self-interest. The better the health indicators in a leader's area of jurisdiction, the higher their reputation for effectiveness, and the higher their localities may be ranked in local or national performance assessments. For this reason, local leaders turn targets set by the Ministry of Health into their own targets, by which their own performance is judged, and on the basis of which their careers may blossom or stagnate.

During the first antenatal consultation, a pregnant woman is made aware of the importance of attending subsequent check-ups. Not all women attend all the recommended four check-ups, however, although large numbers deliver at their local health units. Community health workers play an important role here as well. They accompany women in labour to the health units. In addition to receiving information about the importance of antenatal check-ups, women are advised about family planning and told about the different options available and any side-effects that may be associated with each one. In this way they can make informed choices about what 
methods to use. Although, in general terms, family planning advice can be sought as and when needed, every health facility dedicates one day in a week to family planning consultations.

After women who have delivered at health units return home, community health workers monitor their health to ensure that they report for post-natal check-ups at the appropriate time. As a result of public awareness campaigns and the dedication of community health workers, women of childbearing age in rural Rwanda generally understand the importance of antenatal consultations and post-natal vaccination.

\section{The incentive system}

Behind the level of organisation responsible for the outcomes described in this paper is a unique incentive system, elements of which have also been touched on. The reporting requirements referred to earlier apply at all levels of the sector and are enforced strictly. For example, if a community health worker fails to report on their activities for 14 consecutive days, it is assumed that they are not working. Ordinarily this triggers a phone call, a visit, or summons from their health-facility-based ( $\mathrm{CHW}$ ) coordinator. Elsewhere, reporting is taken seriously enough to compel some data managers and clerks at health facilities to spend nights at work if that is what they have to do to beat strict deadlines. Others put in extra time on weekends to ensure they submit their reports on time.

One of the important drivers of all this is the system of performance contracting, involving all public servants. In local governments they start with district mayors, who sign performance contracts (imihigo) directly with the president. Other local leaders and public servants sign theirs with the mayors or their direct supervisors. The contracts are reviewed on a regular basis against actual performance across a range of domains. The rewards accruing to districts that perform well, and the shame associated with poor performance, are powerful catalysts of the drive to excel. Poor performance invites sanctions that serve to concentrate minds. They include mayors of poorly performing districts being forced to resign by district advisory councils, the districts' legislative and supervisory bodies (Golooba-Mutebi, 2014).

Several weaknesses have been identified in the way that contracts between mayors and the president have been structured and evaluated in the past. They have included cutting corners (gutekinika) and exaggerating achievements, for which some local officials have suffered sanctions, including prosecution and imprisonment. However, their overall impact has been to trigger a competitive spirit among local governments and within them. This accounts for the progress the country has made in domains such as service delivery in the health sector.

Admittedly, the enforcement of performance contracts at lower levels of the administrative system is not as uniformly robust as at higher levels. However, the prospect of identification as a non-performer and being held to account for performing below expectation compels lower-level officials to take their obligations 
seriously. For health workers, performance is linked to financial rewards. The efforts and energies of community health workers, who as volunteers do not earn wages, are rewarded through benefits such as the smart phones they receive to facilitate their work, occasional allowances and cash grants.

The cash grants have been used to establish income-generating projects by cooperatives bringing together $\mathrm{CHWs}$ in their respective areas of coverage. The compensation boosts their morale and avoids the voluntarism fatigue that weakens and destroys similar initiatives elsewhere. ${ }^{27}$ For salaried health workers, the introduction of performance-based financing (PBF) is an important source of motivation. PBF supplements their monthly pay in recognition of good performance. This follows periodic formal evaluations of their activities, using several criteria. PBF was originally intended to raise the quality of health services outside urban areas, by incentivising qualified health workers to seek employment in rural areas.

There are two elements to facility-level evaluation of performance for PBF. The clinical element entails drawing up a matrix to determine indicators of quality of care: punctuality, testing, qualifications of caretakers, good decision making, caring for assets, following guidelines, response to complaints in suggestion boxes, and staff attendance at work. The administrative element focuses on financial reporting, care for and use of equipment, ambulance use and maintenance, cleanliness of toilets, beautification of facility surroundings, provision of mosquito nets on beds and installation of mosquito nets in windows. Facilities that score 90 percent or more get full PBF. Otherwise there are deductions commensurate with the percentage shortfall. Hospitals have therefore had to smarten up their act or risk losing revenue, of which 70 percent goes to capital expenditure while 30 percent is shared out among staff according to specific criteria, including salary scale.

\section{Facilitation}

Usually one of the reasons health workers and their supervisors fail to discharge their duties in developing country contexts is lack of facilitation, which often leads to insurmountable logistical constraints. In Uganda, for example, a key constraint is lack of transport for health workers to perform supervisory and other outreach duties. Where motorised transport is available, there may be no money for fuel. Where money for fuel is available, the vehicles may have broken down, needing repairs for which there is no money. In Rwanda, the government makes a great effort to ensure that health workers are facilitated to carry out their functions. Actors playing critical supervisory roles have the necessary transport facilities in the form of vehicles and motorcycles all of which, under normal circumstances, are well supplied with fuel. To overcome obstacles such as complicated procurement procedures that impair the capacity of health officials elsewhere to repair broken down vehicles, managers of health facilities have the mandate to use their resources for such purposes, subject

\footnotetext{
${ }^{27}$ See, for example, Golooba-Mutebi (1999) on how the system of community health workers in Uganda collapsed during the 1990s.
} 
to financial audits to ensure the resources have been used correctly. Where abuse occurs, appropriate sanctions apply. ${ }^{28}$

Where field supervision is not logistically feasible, say with regard to the numerous community health workers attached to each facility, arrangements are made for fieldbased personnel to attend periodic meetings at the health units to which they are attached. In the case of community health workers, and their facility-based coordinators specifically, in addition to monthly meetings, they and their coordinators have received smartphones for use in communicating with each other and for reporting regularly to their direct supervisors and to the Ministry of Health about their activities. Using the same phones, they alert health workers of health emergencies within their villages. The evacuation of patients from lower-level facilities to district referral hospitals has been made possible by the purchase of ambulances. Every district has six ambulances, some of which are attached to referral hospitals and some to health centres in remote locations. Their attachment to facilities in remote locations is meant to facilitate speedy evacuation of patients, who might otherwise be difficult to evacuate speedily, given they are not within easy reach of ambulances attached to referral hospitals.

Health personnel who are responsible for preparing and submitting reports to the different levels of the administrative and health systems have also been provided with the facilities they need to do so. Hospitals and health units, including small health posts, are equipped with internet-enabled computers and smartphones for transmitting reports to their designated recipients. This has eliminated the need for reports to be transported physically. Consequently, costs associated with physical delivery - which elsewhere include buying cars, fuelling them, hiring drivers, repairing and servicing them, or paying fares on public transport - have been eliminated.

\section{How does politics fit into all this?}

Politics interacts with service delivery at two levels - the national and the local. At the national level, high quality health services and equity in their delivery are central to the government's aspirations of raising the quality of life for all Rwandans, as part of its strategy to heal the divisions of the pre-genocide period. Also, a healthy population is pivotal in the government's aspirations of attaining middle-income status. It cannot realise these ambitions without a population that is hardworking and productive. If poor health is an important factor in the perpetuation of chronic poverty, by rendering people unable to lead productive lives, then good health is essential to poverty reduction and, ultimately, prosperity.

All the government's aspirations as outlined here, and as they apply to other domains, are rooted in the ambitions of the Rwanda Patriotic Front. The RPF aspires to build a new, more confident Rwanda, radically different from the Rwanda of the pre-genocide period, where discrimination in access to services and opportunity was institutionalised:

\footnotetext{
${ }^{28}$ See, for example, Rwembeho (2015).
} 
'Genocide was a defining moment in the history of our country. We refused to be a failed state. We gave a far-reaching call to action and our people heard and rallied. Together we resolved to uplift ourselves from the abyss and to strive to build a new Rwanda, peaceful and stable, and fit for all of us. We understood from the start that our strategy had to be locally driven if we were going to solve the problems engendered by the scourge of genocide. ${ }^{29}$

The government realised early on that achieving its ambition of building a new Rwanda was dependent in part on devising appropriate mechanisms and developing their capacity for implementing the decisions arrived at; and in part on politics that privileged consensus-building and working together over adversarial contestation. In broad terms, this was what the months' long dialogue, known as the urugwiro process, was about. Against this background, the government opted to create local authorities to which it would decentralise responsibility, power and resources for the implementation of policy decisions made at the centre or at the local level.

\section{Decentralisation}

Unlike decentralisation programmes implemented across Africa during the late 1980s and early 1990s, decentralisation in Rwanda did not follow the conventional wisdom prevailing at the time. Unlike other countries that rushed into embracing 'democratic decentralisation', Rwanda opted for gradual change, refraining from creating autonomous local authorities operating under the principle of non-subordination. Instead, it granted limited autonomy to the local authorities, leaving the central government with sufficient powers to influence their conduct and activities.

Although over time many important decisions have come to be made and implemented at local level, where much of the planning and prioritisation takes place, local authorities remain creatures of the centre. Skewed in favour of the centre, the relationship has undermined prospects for the emergence of the kind of elite capture of decentralisation's dividends that is evident in countries such as Uganda. Also, several avenues for popular participation were created to enable citizens to hold leaders to account and to ensure that their preferences influenced planning and prioritisation.

Participation takes place directly through regular community meetings, some of which occur after the monthly communal work (umuganda), others whenever need may arise. Within the health sector, popular participation is indirect. It takes place in local government structures and in health units through special committees ${ }^{30}$ comprising local leaders, health workers and users' representatives. Nonetheless, in the regular neighbourhood meetings, anyone can raise any matter for discussion, which allows those who may have concerns or complaints about the quality of service delivery in the health sector, for example, to do so. Other occasions arise during outreach visits

\footnotetext{
${ }^{29}$ Paul Kagame - Speech at the Woodrow Wilson International Centre for Scholars, 2004.

${ }^{30}$ Management committees (comités de gestion).
} 
by members of parliament, during which they hold public meetings with members of the public, and when the latter are given an opportunity to speak. ${ }^{31}$

Perhaps more important than the autonomy local governments enjoy are the powers of direction and control which the central government has retained. This has allowed it to set priorities that, left to their own devices, local elites may not pay attention to, for implementation at the local level, and to ensure that local governments actually implement them.

The performance contracts signed between elected local leaders and the President of the Republic have also been important, as they oblige them to focus on achieving the priorities determined at both the local and national levels. As we saw earlier, one of the reasons local governments strive to achieve health targets set by the Ministry of Health in Kigali is because they subsequently appropriate them as their own. This is because their achievement has implications for each district's placement in overall performance assessments and, ultimately, for the political careers of the concerned local leaders. ${ }^{32}$

Also important is the decision not to allow political competition at local government level along party lines. Its impact has been that, rather than emphasise their membership in, or support for, this or that political party, candidates emphasise their own personal record and qualities when canvassing for support. It means that, following election, they do not feel compelled to pander to the interests of their narrow constituents. In turn, it means that if they contest again, voters will evaluate their performance and not be influenced necessarily by considerations of whether they are members of this or that political party. Ultimately this approach encourages leaders to focus on issues of local-level importance, not those that may be important to party headquarters in the capital city. In addition, it encourages collaboration among leaders who belong to political parties that at national level also emphasise inter-party consensus-building and collaboration. Perhaps equally important is that the constant scrutiny of local government performance by the centre also leaves little room for divisions or conflicts that may distract local leaders from pursuing the realisation of their own priorities and those set for them by the vigilant and demanding central government.

\section{The influence of national-level politics}

Two features of post-genocide politics and political organisation are key in explaining the advances Rwanda has made as a country and in service delivery. One is the

\footnotetext{
${ }^{31}$ According to a respondent in the Rwanda parliament, during some of the outreach activities he has been involved in, people speak about health services. In one village in southern Rwanda, for example, people informed a group of visiting senators about the head of their health unit not residing in the village, as required by law. He lived in a neigbhbouring trading centre, which meant that he was not available at all times. The senators took up the matter with the health worker and the Ministry of Health. Within days he had relocated back to the village (interview, February 2013).

${ }^{32}$ Ntambara (2009); Mugisha (2009); Kimenyi (2009); Rwembeho (2009); also, GoloobaMutebi (2014).
} 
pursuit of consensus with regard to how to tackle different challenges. It stems from a marked aversion to public displays of disagreement, which in other jurisdictions are part of the performance of politics and to which politicians and the public attach importance as an integral feature of democracy. The other is the sharing of power and responsibility, as manifest in the presence in government of several political parties, all playing central roles in policy making and priority setting.

The emphasis on building consensus, and on sharing power and responsibility among potential rival and adversarial actors, emanates from the RPF's broad vision of building a 'New Rwanda' that is different from the Rwanda in which political divisions made the genocide against the Tutsi not only possible, but also thinkable. This vision has detractors in and outside the country, particularly among advocates of 'political competition', shorthand for adversarial contestation, and within Rwandan refugee communities across the world with prominent RPF opponents. Inside the country, however, there are strong indications that the RPF has been successful in selling it to potentially rival political parties.

These come in two groups: those that are represented in the government by virtue of constitutionally defined criteria; and those that are not in the government, but interface with parties in the government through the National Forum of Political Organisations. The NFPO is a constitutional body funded by the government and serves as a mechanism for building consensus and bringing together all registered political parties in Rwanda.

One implication of this approach to politics and political organisation is that arriving at decisions is relatively easier than in conventional multi-party systems. And after decisions are made, and priorities set, attention shifts quickly to implementation. A senior member of the Social Democratic Party hinted at this: 'Decisions are made quickly and implemented quickly. We do not spend time debating policies we know are good. We may have problems here and there with implementation, but policy making is not a problem'. ${ }^{33}$ There are clear links between the approach and advances in the health sector:

'The political environment has led to a legal framework that has allowed the health sector to succeed. The key is the governance philosophy of inclusion. No one is left behind. It is not a technique; it is a philosophy based on Rwanda's reality. We don't simply talk about it; we implement it. What lies behind the drive for implementation is working together. Working together means that everybody knows about what is supposed to happen. And when it comes to implementation people are made accountable. The consensus approach is very important. ${ }^{34}$

\footnotetext{
${ }^{33}$ Interview, 22 June 2015.

${ }^{34}$ Interview, Ministry of Health, 18 March 2015.
} 
At local government level, performance pressures seeking to ensure that targets embedded in the performance contracts are achieved have added a sense of urgency to the implementation imperative. In addition to the performance contracts, performance pressures come from multiple sources. One is the Office of the Prime Minister (OPM). One of its roles is to monitor ministries with regard to progress towards achieving their performance targets. According to a senior official, 'We can detect early that you have spending challenges. We go to your projects to see what is happening, whether you're actually implementing'. ${ }^{35}$ And all this happens against the background of constant examination and re-examination of options: 'We must be on top of the latest innovations, developments, challenges and statistics'. ${ }^{36}$ This 'learning as we go along' approach testifies to the government's reputation for experimentation and lesson learning (Booth and Golooba-Mutebi, 2014).

Perhaps most significant is the Rwandese Patriotic Front's role in all this. The RPF plays an important role in decision-making in general and in policy formulation in particular. All policies under consideration for adoption are routed through the RPF prior to their consideration by the cabinet. The party has commissions that oversee the different sectors. For health, it is the Commission on Social Welfare. It scrutinises all proposed policies to ensure they conform to the RPF's aspirations as the ruling party and, more broadly, to its core values, among them equity and nondiscrimination. Policy proposals with elements that may run counter to the party's aspirations or that risk violating its values do not proceed to the cabinet for consideration. Instead, they are referred for reformulation or refinement. The party's role, however, does not end here. Once the cabinet approves policies for implementation, the party keeps a watchful eye:

'We monitor what is supposed to be accomplished within a certain period. We ask those who are responsible if they are doing as planned. We follow up on what is going on in the government where we are not, through our members who work in government. ${ }^{, 37}$

The monitoring includes regular and direct interfacing between the party leadership and ministers or senior officials in connection with specific aspects of their work. The objective is to ensure that decisions are implemented as agreed, and that where difficulties may arise, they can be addressed without undue delay:

'They are extremely active. Almost everything and anything I did, I would do it with the RPF. Whatever I felt needed changing at the policy level the RPF would come in. Whatever an RPF minister wants to table at cabinet, the RPF has to know and make an input if

\footnotetext{
35 Interview, OPM, 15 June 2015.

36 Interview, Strategy and Policy Unit, Office of the President, 25 May 2015.

${ }^{37}$ Interview, RPF secretariat, June 2015.
} 
necessary. ${ }^{38}$ I had not realised how much work they do before I became a minister. Even at technical level they get involved. I am the doctor. I make a presentation, and someone fires me a question that is relevant and pertinent. It was a very positive experience for me. I would go in (for meetings at the secretariat) and come out with an insight I did not have before going in. 39

'They keep an eye on how things are going. They call people to do presentations and keep members informed about developments. Coordinators are continuously calling and asking how things are going, and questioning where they feel things are not progressing well. Members of parliament go upcountry, hear and see things, and report back to parliament and the party. I used to go to the secretariat to provide information. Sometimes I was asked to prepare reports or react to discussions on radio talkshows. ${ }^{40}$

The role of the ruling party is bolstered by President Kagame's own role and influence as CEO of Rwanda Inc. (Crisafulli and Redmond, 2012). His role and influence operate at two levels: encouragement, facilitation, and inspiration on the one hand; and pushing and enforcing on the other. First, the pushing and enforcing:

'He wants things to get better. So he follows everything. People know he is following up on what they are doing. They fear him, so they get things done. If he were a less strict president, things would get stuck somewhere. $^{.41}$

'He is a single-man watchdog over the health sector. At times you will be required to report every week on a specific day. I used to submit reports every Wednesday to the Office of the President and to the Office of the Prime Minister. The president goes into details. He wants to understand how things happen. He takes a very strong interest in knowing, understanding and holding people to account. ${ }^{42}$

And then facilitation, encouragement and inspiration:

'He guides. He makes us reflect and gets us to ask ourselves questions. He's very democratic. He lets people debate. Through discussion he brings up things that others have not thought about. He breaks large visions into realistic steps. He imagines solutions to

\footnotetext{
${ }^{38}$ The party does not summon ministers that belong to other political parties. It communicates with them through their permanent secretaries who in that case will be members of the party. Permanent Secretaries are appointed on party basis.

${ }^{39}$ Interview with a former Minister, April 9, 2015.

${ }^{40}$ Interview with a former senior MoH official, April 8, 2015.

${ }^{41}$ Interview with a senior government official (also senior member of the opposition Social Democratic Party), 15 March 2015.

${ }^{42}$ Interview with a former senior MoH technical officer, 9 April 2015.
} 
problems and then brings others on board through educative steps. We Rwandans are not better than other people; we are better guided. ${ }^{43}$

\section{The policy process: Ideas and the role of foreign actors}

Up to this juncture there is hardly mention of the role of external actors and dominant policy ideas which permeate international development agendas that wind up as local agendas within developing countries. As with its counterparts elsewhere in the developing world, the government of Rwanda comes under the heavy influence of international aspirations, such as the drive to stem the tide of maternal mortality and others, such as the pursuit of the Millennium Development Goals (MDGs) and now the Sustainable Development Goals (SDGs).

However, while it embraces many external ideas and influences, the government is notable for its determination to make its own choices in line with local realities. As a senior official pointed out, 'Priorities are decided in Rwanda. No donor or NGO can do anything that the government does not agree with'. ${ }^{44}$ And the government's will not to lose sight of its own priorities is exemplified by President Kagame's reported attitude towards the MDGs: 'I understand this is what the MDG people want. But what do we want for our people?' Because of this pressure to go beyond wanting to hit the MDG targets, 'most of our targets were much higher than the MDGs' ${ }^{45}$

Donors are important actors in Rwanda, in as far as they provide a large percentage of the money funding development. The sector is itself heavily donor-dependent (Figure 5).

However, unlike countries such as Uganda, where donors and other actors such as NGOs exercise a lot of influence over policy-making and play important direct roles in implementation, in Rwanda the government has successfully asserted itself in what is a very delicate relationship:

'Whatever they fund is aligned to the national plan. Rwanda is our home. You are the boss in your home. What should happen is that which you allow to happen. Rwandans know best what they need. Donors come in to fund what has been decided. Where they have a better idea, we take it on board and then we do things together. ${ }^{46}$

In other countries, officials complain of donors setting priorities and deciding where to direct their resources without restraint from governments, not least because the latter take the view that since it is their money, donors should decide where and how to spend it, often creating new implementation structures running parallel to those of the government. Such is the attitude of the government of Uganda, as pointed out by a

\footnotetext{
${ }^{43}$ Interview with a senior RPF minister of many years, 18 March 2015.

44 Interview, 9 April 2015.

${ }^{4}$ Interview with a former senior MoH official, 9 April 2015.

${ }^{46}$ Interview, 18 March 2015.
} 
Figure 5: Sources of funding

Top 12 funding sources ${ }_{100}^{\text {Billions in RWF }}$

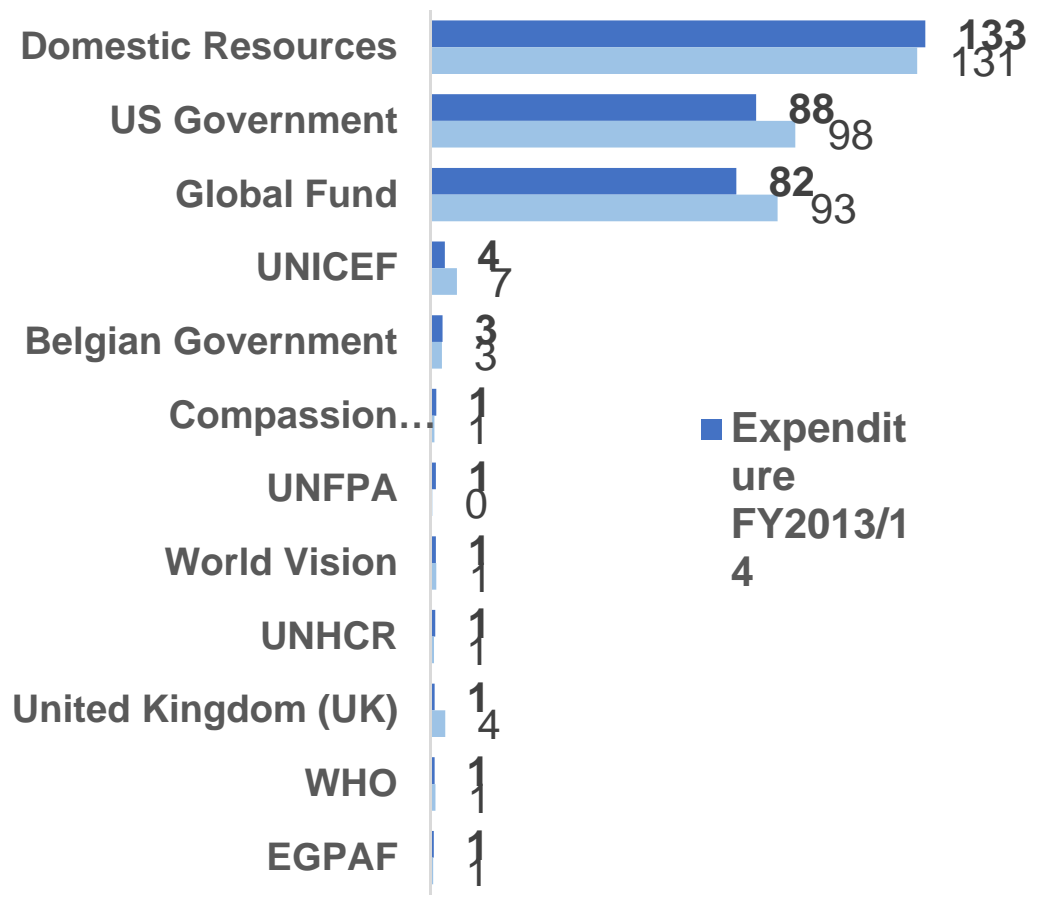

Source: $\mathrm{MoH}$.

senior official and former minister of health. ${ }^{47}$ Officials and other actors in the health sectors complain most especially about 'vertical programmes', donor initiatives that focus on single issues or diseases such as HIVIAIDS.

The government of Rwanda, on the other hand, insists on vertical programmes addressing issues and problems that have been identified internally - with donor support - as priority areas and which are well articulated in such policy frameworks as Vision 2020. A senior official outlined their approach:

'Vertical programmes come as vertical programmes, and then the money is used to fund the sector as a whole. For example, laboratories funded by money for HIVIAIDS serve the system as a whole. Programmes for HIV are therefore adapted to address health generally. There are no separate structures for vertical programmes. Ordering HIVIAIDS drugs through the government strengthens the general drug supply chain. The M \& E system for HIVIAIDS includes other diseases. Integration strengthens the whole health system. ${ }^{48}$

\footnotetext{
${ }^{47}$ Interview, 13 April 2015.

${ }^{48}$ Interview, 18 March 2015.
} 


\begin{abstract}
'Binagwaho ${ }^{49}$ has been resolute in keeping donors on a short leash. She tells them: "We know we are poor and need help. But help us to do what we want to do." Otherwise you go and spend your money elsewhere. Equally important is the president's support for this approach. As for NGOs, if an NGO wants to do something in a district, the mayor will be contacted to give a view. If he or she says "we do not need help there, but here", the NGO must choose between taking their money away or doing that which the district wants to be helped with. There is a time when NGOs would do things according to their own thinking and without the knowledge of local leaders. That ended. ${ }^{50}$
\end{abstract}

Relations with donors have also been streamlined through the government's insistence on a 'donor division of labour', which the Ministry of Finance insisted on unlike in many other aid-recipient countries - in order to improve donor efficiency. It entails donors being directed into sectors in which they enjoy comparative advantage. This has reduced the number of donors trying to do things or fund initiatives in each sector, rendering them more manageable and cutting transaction costs and the time that officials at the Ministry of Finance and in other domains spend interfacing with their representatives.

\title{
Discussion and conclusions
}

It is too early to tell whether the alignment of political interests among the different groups of elites behind Rwanda's current political settlement will endure in the long term. However, the role it has played in getting them to rally behind or support the RPF's 'New Rwanda' project, and in providing a stable environment in which development and social change could be pursued with consistency, is evidently clear. There are many reasons why Rwanda has made the progress it has, and defied predictions that envisaged it becoming another of Africa's failed states.

International goodwill and generosity by the donor community have been key factors. The broken state and dislocated society that the RPF and its political partners inherited would have been extremely difficult to re-order and reconstitute, and the history of division difficult to reverse, if the international community had withheld its goodwill and the resources that have financed the economic and social gains to which the government owes a significant amount of its legitimacy. More important, in the absence of order and stability - the foundations on which everything else depends - it is unlikely that the goodwill and resources would have made the kind of difference that they have. Order and stability, as we have shown, would most likely have been impossible to establish in a context of a quick return to competitive adversarial, winner-takes-all politics, against the background of the country's postcolonial political culture of systematic discrimination and exclusion. In the health sector, as in other sectors, the post-genocide political settlement and its emphasis on

\footnotetext{
${ }^{49}$ Agnes Binagwaho, former Minister of Health.

${ }^{50}$ Interview, 9 April 2015.
} 
consensus-building in pursuit of common goals embodied in the 'New Rwanda' project has been the most important factor behind the successes that have been achieved. 


\section{References}

Adelman, H. (2000). 'Canadian policy in Rwanda'. In H. Adelman and A. Suhrke (eds.), The Rwanda Crisis from Uganda to Zaire: The Path of a Genocide. New Brunswick, NJ and London: Transaction Publishers.

Booth, D. and Cammack, D. (2013). Governance for Development in Africa. Solving Collective Action Problems. London: Zed Books.

Booth, D. and Golooba-Mutebi, F. (2014). 'Policy for agriculture and horticulture in Rwanda: a different political economy?' Development Policy Review 32(S2): s173-s198.

Booth, D. and Golooba-Mutebi, F. (2012a). 'Policy for agriculture and horticulture in Rwanda: A different political economy?' Working Paper 38, Future Agricultures Consortium.

Booth, D. and Golooba-Mutebi, F. (2012b). 'Developmental patrimonialism? The case of Rwanda'. African Affairs, 111(444): 379-403.

Callamard, A. (2000). 'French policy in Rwanda'. In H. Adelman and A. Suhrke (eds.), The Rwanda Crisis from Uganda to Zaïre: The Path of a Genocide. New Brunswick, NJ and London: Transaction Publishers.

Chambers, V. and Golooba-Mutebi, F. (2012). Is the Bride Too Beautiful? Safe Motherhood in Rural Rwanda. Research Report 04. London: Africa Power and Politics Programme, Overseas Development Institute.

Communauté Rwandaise de France (1990). 'Memorandum sur la Crise Politique Actuelle au Rwanda'. December.

Crisafulli, P. and Redmond, A. (2012). Rwanda, Inc.: How a Devastated Nation Became an Economic Model for the Developing World. New York: Palgrave Macmillan.

de Forges, A. (1999). Leave None To Tell the Story: Genocide in Rwanda. New York: Human Rights Watch.

Di John, J. and Putzel, J. (2009). 'Political settlements: Issues paper'. Governance and Social Development Resource Centre, University of Birmingham, June.

Foley. E. E. (2010). Your Pocket Is What Cures You. The Politics of Health in Senegal. New Brunswick, NJ and London: Rutgers University Press. 
Gachuruzi, S. B. (2000). 'The role of Zaïre in the Rwandese conflict'. In Adelman, H. and Suhrke, A. (eds.), The Rwanda Crisis from Uganda to Zaire: The Path of a Genocide. New Brunswick, NJ and London: Transaction Publishers.

Gagliardone, I. and Golooba-Mutebi, F. (2016). 'The evolution of the internet in Rwanda and Ethiopia: Towards a "developmental" model?' International Journal of Security and Development 5(1): 1-24.

Gakusi, A. E and Mouzer, F. (2010). De la Révolution Rwandaise à la ContreRévolution: Contraintes Structurelles et Gouvernance 1950-2003. Paris: L'Harmattan.

Golooba-Mutebi, F. (2014). 'Holding local governments accountable the unfashionable Rwanda way'. The East African, 6 December. Available online: http://www.theeastafrican.co.ke/OpEd/comment/Holding-local-govtaccountable-the-unfashionable-Rwanda-way/434750-2546736nq9s44/index.html (accessed 26 September 2016).

Golooba-Mutebi, F. (2011). 'If you're pregnant and poor, the best place to give birth in EA is Rwanda'. The East African, 18 April Available online: http://mobile.theeastafrican.co.ke/Opinion/-/433846/1146046//format/xhtml/item/2/-/q95m5t/-/index.html (accessed 29 September 2016).

Golooba-Mutebi, F. (2005). 'When popular participation won't improve service provision: Primary health care in Uganda'. Development Policy Review 23(2):165-182, March.

Golooba-Mutebi, F. (1999). Decentralisation, Democracy and Development Administration in Uganda, 1986-1996: Limits to Popular Participation. Unpublished PhD dissertation, University of London.

Golooba-Mutebi, F. and Booth, D. (2013). Bilateral Cooperation and Power Dynamics in Rwanda. Report prepared for the Embassy of Sweden in Rwanda.

Golooba-Mutebi, F and Bukenya, B. (2014). Institutional and Political Economy Analysis of the Health Sector in Uganda. Report prepared for DFID-Uganda, April.

Golooba-Mutebi, F. and Tollman, S. M. (2007). 'Shopping for health: Affliction and response in a South African village'. African Sociological Review 11(2): 64-79.

Gourevitch, P. (2000). We Wish to Inform You that Tomorrow We Will Be Killed with Our Families. New York: Picador. 
Hickey, S. (2012). 'Investigating the politics of inclusive development: towards a relational approach'. ESID Working Paper 1. Manchester: Effective States and Inclusive Development Research Centre, The University of Manchester.

Jaffre, Y. and de Sardan, J.-P. (eds.) (2003) Une Médecine Inhospitalière. Les Difficiles Relations entre Soignants et Soignés dans Cinq Capitales d'Afrique de l'Ouest. Paris: Karthala.

Jewkes, R., Abrahams, N. and Mvo, Z. (1998). 'Why do nurses abuse patients? Reflections from South African obstetric services'. Social Science and Medicine 47(11): 1781-1795.

Khan, M. (2010). 'Political settlements and the governance of growth-enhancing institutions'. London: SOAS, Mimeo.

Kimenyi, F. (2009). '50\% elected local leaders out of office'. The New Times, 23 July.

Kinzer, S. (2008). Thousand Hills: Rwanda's Rebirth and the Man Who Dreamed It. Hoboken, NJ: John Wiley and Sons.

Langwick, S. A. (2011). Bodies, Politics and African Healing. Bloomington and Indianapolis, IN: Indiana University Press.

Leliveld, A., Hart, C.'t, Gnimadi, J. and Dekker, M. (2010). 'Can't buy me health: Financial constraints and health-seeking behaviour in rural households in central Togo'. In Dekker, M. and R. van Dijk (eds.), Markets of Well-being: Navigating Health and Healing in Africa. Leiden and Boston, MA: Brill.

Levy, B. (2014). Working with the Grain: Integrating Governance and Growth in Development Strategies. New York: Oxford University Press.

Maina, C. P. and Kibalama, E. (eds.) (2006). Searching for Sense and Humanity: Civil Society and the Struggle for a Better Rwanda. Kampala, Uganda: Fountain Publishers.

Muganwa, G. (2012). 'Independence, first witness account'. Interview of Patrick Mazimhaka, a survivor of the 1950 s pogroms and founder member of the RPF. Rwanda Dispatch 48, July.

Mugisha, S. (2009). 'Council approves Mayor's resignation'. 29 July.

Neema, S.B. (1994). Mothers and Midwives: Maternity Care Options in Ankole, Southwestern Uganda. PhD dissertation. Institute of Anthropology, University of Copenhagen, Denmark. 
Nkunzumwami, E. (1996). La Tragédie Rwandaise: Historique et Perspectives. Paris: L'Harmattan.

North, D. C., Wallis, J. J. and Weingest, B. R. (2009). Violence and Social Orders: A Conceptual Framework for Interpreting Recorded Human History. Cambridge: Cambridge University Press.

Ntambara, P. (2009). 'Another mayor resigns'. The New Times, 6 May.

Otunnu, O. (2000a). 'Rwandese refugees and immigrants in Uganda'. In Adelman, H. and Suhrke, A. (eds.), The Rwanda Crisis from Uganda to Zaire: The Path of a Genocide. New Brunswick, NJ and London: Transaction Publishers.

Otunnu, O. (2000b). 'An historical analysis of the invasion by the Rwanda Patriotic Army (RPA)'. In Adelman, H. and Suhrke, A. (eds.), The Rwanda Crisis from Uganda to Zaire: The Path of a Genocide. New Brunswick, NJ and London: Transaction Publishers.

Parks, T. and Cole, W. (2010). 'Political settlements: Implications for international development policy and practice'. San Francisco, CA: The Asia Foundation Occasional Paper 2.

Prunier, G. (1997). The Rwanda Crisis: History of a Genocide. London: Hurst and Co.

Reyntjens, F. (2013). Political Governance in Post-Genocide Rwanda. Cambridge: Cambridge University Press.

Reyntjens, F. (2004). 'Rwanda, ten years on: From genocide to dictatorship'. African Affairs 103(4): 177-210.

Reyntjens, F. (1994). L'Afrique des Grands Lacs en Crise: Rwanda, Burundi: 19881994. Paris: Karthala.

Rwembeho, S. (2015). 'Three hospital directors arrested over embezzlement'. The New Times, 26 October.

Rwembeho, S. (2009). 'Bugesera district mayor resigns'. The New Times, 24 July.

Rusatira, L. (2005). Rwanda: Le Droit à l'Espoir. Paris: L'Harmattan.

Scheper-Hughes, N. (1992). Death without Weeping. The Violence of Everyday Life in Brazil. Berkeley, LA: University of California Press.

Strauss, S. (2006). The Order of Genocide: Race, Power, and War in Rwanda. Ithaca, NY: Cornell University Press. 
Turshen, M. (1999). Privatizing Health Services in Africa. New Brunswick, NJ and London: Rutgers University Press.

Uvin, P. (1997). Aiding Violence: The Development Enterprise in Rwanda. West Hartford, CT: Kumarian Press. 


\section{esid}

\section{The Effective States and Inclusive Development Research Centre}

The Effective States and Inclusive Development Research Centre (ESID) aims to improve the use of governance research evidence in decision-making. Our key focus is on the role of state effectiveness and elite commitment in achieving inclusive development and social justice.

ESID is a partnership of highly reputed research and policy institutes based in Africa, Asia, Europe and North America. The lead institution is the University of Manchester.

The other institutional partners are:

- $\quad$ BRAC Institute of Governance and Development, BRAC University, Dhaka

- $\quad$ Center for Democratic Development, Accra

- $\quad$ Center for International Development, Harvard University, Boston

- Department of Political and Administrative Studies, University of Malawi, Zomba

- $\quad$ Graduate School of Development, Policy \& Practice, Cape Town University

- Institute for Economic Growth, Delhi

In addition to its institutional partners, ESID has established a network of leading research collaborators and policy/uptake experts. 